\title{
Normative Estimation of Parameters of the Blast-Furnace Smelting
}

\section{Tovarovskiy Iosif Grigorevich}

Iron and Steel Institute National Academy of Science of Ukraine, Iron Department, Dnepr, Ukraine

\section{Email address:}

tovarovskig@gmail.com

\section{To cite this article:}

Tovarovskiy Iosif Grigorevich. Normative Estimation of Parameters of the Blast-Furnace Smelting. Advances in Materials. Vol. 6, No. 4, 2017, pp. 38-44. doi: 10.11648/j.am.20170604.12

Received: July 5, 2017; Accepted: August 3, 2017; Published: August 28, 2017

\begin{abstract}
The methodological tool developed earlier and used at enterprises for estimating the influence of the parameters of blast furnace smelting on coke consumption and productivity has been substantially supplemented and refined based on the results of the analytical and experimental studies performed, as well as the generalization of the experience of blast furnaces. The latter option provides for a quantitative assessment of the effect on the consumption of coke on the distribution of charge materials during loading.
\end{abstract}

Keywords: Parameters, Blast Furnace Smelting, Coke Consumption, Charge, Technology

\section{Introduction}

The regulatory impact assessment of the parameters of the blast furnace to the coke consumption and blast furnace productivity refers to the definition of magnitude of change in coke consumption and performance when modifying the individual parameters of melting and their combination. The presence of such assessment, it is necessary to perform operational analysis of the technology, the performance of which depends on the completeness and quality of information used.

For the first time the technique of factor analysis was developed in the late 80 - ies of the last century. After a series of discussions in enterprises and institutions of the sector, methods were considered at all-Union meetings of blast furnace, and then was approved as an industry policy paper in 1987 [1-4]. Further, the document specified in individual items in the metallurgical enterprises on the basis of practical data, analytical and experimental studies [5-11].

\section{Methodical Bases of Formation of "Simple" Dependencies in a Large System "Blast Melting"}

During the study of the impact of individual factors on the indices of blast-furnace revealed its dependence on a set of associated conditions. Therefore, the evaluation of this impact cannot always becuous and largely depends on the task.

In the case of an isolated assessment of a particular factor should consider the whole complex of associated conditions. When comparing the various periods of work to-day furnaces, when the separate components of this factor is already accounted for other factors, the value of its influence is limited to essential ingredient in order to avoid of "double counting".

Operational analysis of changes in indicators of melting often use summary normalized coefficients counting coke consumption and productivity of the furnace, drawn up according to different data. The disadvantage of such briefs is not-interrelatedness of factors leading to errors in their absolute values and re-accounting of individual components effects in terms of the various factors.

For correct accounting of factors when analyzing the indices of blast-furnace needs to be taken to use special techniques, which are an integral part of metal-using the technique, the rationale and contents of which are summarized below.

The methodology is intended for use when analyzing the changes of specific consumption of coke and blast-furnace productivity caused by changes of the technological parameters of blast-furnace smelting. Such analysis is performed in comparison provision of periods of work of 
blast furnaces with different values of technological parameters of blast-furnace smelting, determining the value of a specific consumption of coke and performance (factor analysis). The basis of this analysis, lie the quantitative ratio between changed parameters (factors) and specific consumption of coke by productivity of blast furnaces), which define are empirically or analytically.

To get reliable results on the basis of empirical material need to connect it to a single logically consistent basis. Such a basis are the results of the analytical study of the process that acquire real content in contact with empirical material.

On the basis of established relationships completed an analysis of available experimental data, obtained in different conditions, and selected the most reliable of them. Summarized by these practices used for the adjustment of the figures derived analytically.

The results of the analysis with references to primary sources are given in the author's monograph "Cognition of processes and development of blast furnace technology" [8] and in Table 1 gives a summary of technological factors and the magnitude of their influence on the specific consumption of coke and the productivity of blast furnaces, established in the manner outlined, as well as references to the main sources containing the most characteristic results of the actual influence of technological factors on the specific coke consumption and productivity of blast furnaces.

In table 1 provides a summary of the technological factors and magnitude of their impact of the specific consumption of coke and productivity of blast furnaces installed given way, and links to primary sources, containing the most characteristic result of the actual influence of technological factors on the specific coke consumption and productivity of blast furnaces. When using data tables for mapping of periods of work of blast furnaces with different parameters and analysis of factors a specific consumption of coke and performance assume linearity and the autonomy of the influence of the each factor. In reality, the influence of the factors on the specific coke consumption and performance is non-linear and non-additively.

His character determined the General principles of interrelation of parameters of blast-melting set out in the article of Tovarovskiy I. G. The Philosophy of the Blast Smelting: Cognition and development of the technology [11], on the basis of which the estimation of the influence of each parameter on the consumption of coke and performance shall be based on the absolute value of the value parameter (the higher it is, the less the amount of influence), in combination with other parameters (some may reinforce other-other weakening effect), the General level of perfection of the process (the higher it is, the less the effect of all parameters). The overall level of process perfection (the higher it is, the less the effect of all parameters). This complex of general laws of melting processes is expressed in the form of three principles of functioning and properties of a large system of Blast Furnace Melting:

Principles are: the attenuation, a combination, limiting states.

The properties: adaptivity, spontaneous shifts, multicontinuity.

Therefore, the ranges of real values of some parameters of a break on the intervals within which without a considerable error of communication can be considered linear, and the velua the influence of some factors on the consumption of coke and performance of furnaces are given depending on the average level of other factors.

Shown in the table 1 factors are grouped into three categories: charge (items 1-13), gas-blowing (items 14-20, 25) and organizational (items 22-24). Following are the features of formation and accounting of each category of factors.

Table 1. Influence of technological factors on the specific consumption of coke and productivity of the blast furnace.

\begin{tabular}{|c|c|c|c|}
\hline \multirow{2}{*}{ № } & \multirow{2}{*}{ Factors and units } & \multicolumn{2}{|l|}{+ increase, - decrease } \\
\hline & & consumption coke, $\%$ & productivity, \% \\
\hline \multirow{4}{*}{1} & $\begin{array}{l}\text { Elevated levels of iron in each } 1 \% \text { (in all of the mixture without coke and } \mathrm{CO}_{2} \text { flux) } \\
\text { within up to } 50 \%\end{array}$ & $-1,4$ & $+2,4$ \\
\hline & Within $50-55 \%$ & $-1,2$ & $+2,0$ \\
\hline & Within $55-60 \%$ & $-1,0$ & $+1,7$ \\
\hline & The same, reducing the amount of slag on every $10 \mathrm{~kg} / \mathrm{t}$ of cast iron & $-0,35$ & $+0,6$ \\
\hline 2 & Increased consumption of pure metal-additives $(100 \% \mathrm{Fe})$ for every $10 \mathrm{~kg} / \mathrm{t}$ of cast iron & $-0,4$ & $+0,6$ \\
\hline \multirow{2}{*}{3} & Reducing consumption of raw limestone for every $10 \mathrm{~kg} / \mathrm{t}$ of cast iron & $-0,5$ & $+0,5$ \\
\hline & The same, dolomitized & $-0,4$ & $+0,4$ \\
\hline 4 & Reduction of the content of the fraction $5-0 \mathrm{~mm}$ in the iron containing charge on each $1 \%$ & $-0,5$ & $+1,0$ \\
\hline \multirow[t]{2}{*}{5} & Reduction of ash content in coke for every $1 \%$ & $-1,3$ & $+1,3$ \\
\hline & Reduction of the sulfur content in the coke for every $0.1 \%$ of $[\mathrm{S}]=0,05 \%$ & $-0,18$ & $+0,18$ \\
\hline \multirow{4}{*}{6} & When $[S]=0,04 \%$ & $-0,22$ & $+0,22$ \\
\hline & When $[S]=0,03 \%$ & $-0,27$ & $+0,27$ \\
\hline & When $[S]=0,02 \%$ & $-0,38$ & $+0,38$ \\
\hline & when $[S]=0,01 \%$ & $-0,71$ & $+0,71$ \\
\hline \multirow{3}{*}{7} & Increase of durability of coke: & & \\
\hline & 7.1. by the indicator $\mathrm{M}_{25}(\% / \%)$ : & $-0,6$ & $+0,6$ \\
\hline & 7.2. by the indicator CSR $(\% / \%)$ : & $-0,7$ & $+0,7$ \\
\hline 8 & Reduction of coke abrasion on the indicator $\mathrm{M}_{10}$ for every $1 \%$ & $-2,8$ & $+2,8$ \\
\hline \multirow{2}{*}{9} & Reduction in the content of coke: fraction $+80 \mathrm{~mm}$ (for each $1 \%$ ); & $-0,2$ & $+0,2$ \\
\hline & fraction $-25 \mathrm{~mm}$ (for each $1 \%)$ & $-1,0$ & $+1,0$ \\
\hline 10 & Substitution of coke by lump anthracite, $\mathrm{kg} / \mathrm{kg}$ & $0,8-1,0$ & \\
\hline
\end{tabular}




\begin{tabular}{|c|c|c|c|}
\hline \multirow{2}{*}{ № } & \multirow{2}{*}{ Factors and units } & \multicolumn{2}{|l|}{+ increase, - decrease } \\
\hline & & consumption coke, $\%$ & productivity, $\%$ \\
\hline \multirow[t]{2}{*}{11} & Reduction in the content of silicon in the iron per $0.1 \%$ & $-1,2$ & $+1,2$ \\
\hline & Reduction in the content of manganese in the iron per $0.1 \%$ & $\mathrm{\kappa g} / \mathrm{t}$ & $\%$ \\
\hline \multirow{3}{*}{12} & when $30 \%$ of Mn ore output & $-1,17$ & $+0,22$ \\
\hline & when $20 \%$ of Mn ore output & $-1,76$ & $+0,35$ \\
\hline & when $15 \%$ of Mn ore output & $-2,27$ & $+0,44$ \\
\hline \multirow[t]{5}{*}{13} & $\begin{array}{l}\text { Reduction of phosphorus content in cast iron per } 0.1 \% \\
\text { Increased sulfur content in iron: }\end{array}$ & $-0,6$ & $+0,6$ \\
\hline & 14.1. In case of the arrival of sulfur $10 \mathrm{~kg} / \mathrm{t}$ : & $(\mathrm{kg} / \mathrm{t}:)$ & $\%$ \\
\hline & $0,04-0,05 \%$ & $-3,3$ & $+0,6$ \\
\hline & $0,03-0,04 \%$ & $-5,5$ & $+1,1$ \\
\hline & $0,02-0,03 \%$ & -11 & $+2,0$ \\
\hline \multirow[t]{14}{*}{14} & $0,01-0,02 \%$ & -33 & $+6,5$ \\
\hline & 14.2. In case of the arrival of sulfur $4 \mathrm{~kg} / \mathrm{t}$ : & & \\
\hline & $0,04-0,05 \%$ & $-1,3$ & $+0,25$ \\
\hline & $0,03-0,04 \%$ & $-2,2$ & $+0,4$ \\
\hline & $0,02-0,03 \%$ & $-4,4$ & $+0,8$ \\
\hline & $0,01-0,02 \%$ & $-13,3$ & $+2,5$ \\
\hline & Increasing the temperature of the blast each $10^{\circ} \mathrm{C}$ in the ranges: & & \\
\hline & $800-900^{\circ} \mathrm{C}$ & $-0,50$ & $+0,50$ \\
\hline & $900-1000^{\circ} \mathrm{C}$ & $-0,40$ & $+0,40$ \\
\hline & a) when the concentration of oxygen in the blast up to $25 \%$ & & \\
\hline & $1000-1100^{\circ} \mathrm{C}$ & $-0,30$ & $+0,30$ \\
\hline & $1100-1200^{\circ} \mathrm{C}$ & $-0,28$ & $+0,28$ \\
\hline & $1200-1300^{\circ} \mathrm{C}$ & $-0,25$ & $+0,25$ \\
\hline & $1300-1400^{\circ} \mathrm{C}$ & $-0,22$ & $+0,22$ \\
\hline \multirow{11}{*}{15} & b) when the concentration of oxygen in the blast $25-35 \%$ & & \\
\hline & $1000-1100^{\circ} \mathrm{C}$ & $-0,25$ & $+0,25$ \\
\hline & $1100-1200^{\circ} \mathrm{C}$ & $-0,20$ & $+0,20$ \\
\hline & $1200-1300^{\circ} \mathrm{C}$ & $-0,20$ & $+0,20$ \\
\hline & $1300-1400^{\circ} \mathrm{C}$ & $-0,18$ & $+0,18$ \\
\hline & c) when the concentration of oxygen in the blast $35-40 \%$ & & \\
\hline & $1000-1100^{\circ} \mathrm{C}$ & $-0,20$ & $+0,20$ \\
\hline & $1100-1200^{\circ} \mathrm{C}$ & $-0,18$ & $+0,18$ \\
\hline & $1200-1300^{\circ} \mathrm{C}$ & $-0,16$ & $+0,16$ \\
\hline & $1300-1400^{\circ} \mathrm{C}$ & $-0,14$ & $+0,14$ \\
\hline & A decrease in humidity blast on each $1 \mathrm{~g} / \mathrm{m}^{3}$ at a rate of blast: & & \\
\hline \multirow[t]{4}{*}{16} & $1500-1600 \mathrm{~m}^{3} / \mathrm{t}$ & $-0,20$ & $+0,14$ \\
\hline & $1000-1100 \mathrm{~m}^{3} / \mathrm{t}$ & $-0,15$ & $+0,06$ \\
\hline & Enrichment of blast oxygen for every $1 \%$ (abs.) in focus: & & \\
\hline & Up to $25 \%$ & $+0,50$ & $+2,0$ \\
\hline \multirow[t]{4}{*}{17} & $25-30 \%$ & $+0,80$ & $+1,7$ \\
\hline & $30-35 \%$ & $+1,10$ & $+1,4$ \\
\hline & $35-40 \%$ & $+1,40$ & $+1,6$ \\
\hline & Factor replacement of coke by coke oven gas at a flow rate: & & \\
\hline \multirow[t]{3}{*}{18} & Up to $200 \mathrm{~m}^{3} / \mathrm{t}$ & $0,45 \mathrm{\kappa g} / \mathrm{m}^{3}$ & \\
\hline & $200-300 \mathrm{M}^{3} / \mathrm{t}$ & $0,40 \mathrm{\kappa g} / \mathrm{m}^{3}$ & \\
\hline & Factor replacement of coke by natural gas at a flow rate: & & \\
\hline \multirow{3}{*}{19} & Up to $100 \mathrm{~m}^{3} / \mathrm{t}$ & $0,80 \kappa \mathrm{k} / \mathrm{M}^{3}$ & - \\
\hline & $100-150 \mathrm{~m}^{3} / \mathrm{t}$ & $0,60 \mathrm{\kappa g} / \mathrm{m}^{3}$ & - \\
\hline & $150-200 \mathrm{~m}^{3} / \mathrm{t}$ & $0,40 \mathrm{\kappa g} / \mathrm{m}^{3}$ & - \\
\hline 20 & Factor replacement of coke by fuel oil & $1,2 \mathrm{\kappa g} / \mathrm{kg}$ & - \\
\hline \multirow{4}{*}{21} & Factor replacement crushed coke by coals: & & \\
\hline & anthracite and skinny with ash content up to $10 \%$ & 0,9 кг/кг & - \\
\hline & the same, with an ash content of $10-20 \%$ & 0,8 кг/кг & - \\
\hline & gas, with an ash content of $10-20 \%$ & 0,8 кг/кг & - \\
\hline 22 & $\begin{array}{l}\text { The increased pressure of top gases for every } 10 \mathrm{kPa} \text { in the range up to } 200 \mathrm{kPa} \text { (excess) } \\
\text { with a corresponding increase in the mass of the blast }\end{array}$ & $-0,20$ & $+1,0$ \\
\hline 23 & Decrease short-downtimes by $1 \%$ & $-0,50$ & $+1,5$ \\
\hline 24 & Reduction of time of slow run at $1 \%$ & $-0,50$ & $+1,0$ \\
\hline 25 & $\begin{array}{l}\text { The reduction of cases of delays the release of pig-iron for every } 1 \% \text {, with the average } \\
\text { duration of the delay of } 0.5 \text { interval of time between adjacent releases }\end{array}$ & $-0,05$ & $+0,1$ \\
\hline \multirow[t]{2}{*}{26} & $\begin{array}{l}\text { The increase the forcing on the blast-melting process by an increase in the differential } \\
\text { pressure gases for every } 1 \% \text { up to the boundary values }\end{array}$ & - & $+0,50$ \\
\hline & The same, but above the boundary values & $+0,2$ & $+0,30$ \\
\hline 27 & $\begin{array}{l}\text { Increased uniformity of distribution of ore loads on the radius of the furnace top for conical } \\
\text { charging devices }\end{array}$ & $-(0-2,0) \%$ & $+(0-2,0) \%$ \\
\hline
\end{tabular}




\begin{tabular}{|c|c|c|c|}
\hline \multirow{4}{*}{ № } & \multirow{2}{*}{ Factors and units } & \multicolumn{2}{|l|}{+ increase, - decrease } \\
\hline & & consumption coke, $\%$ & productivity, $\%$ \\
\hline & Same for bell-less charging devices & $-(0-3,0) \%$ & $+(0-3,0) \%$ \\
\hline & Replacement a conical by bell-less charging device & $-4 \%$ & $+4 \%$ \\
\hline 28 & $\begin{array}{l}\text { Reduction of heat removal from the walls of the furnace by } 1 \% \text { relative to the total ward } \\
\text { heat, } \%\end{array}$ & $\begin{array}{l}-100 / \mathrm{dq} \text {, where: dq- the } \\
\text { proportion of useful heat, } \%\end{array}$ & $\begin{array}{l}-100 / \mathrm{dq} \text {, where: } \\
\text { dq- the proportion } \\
\text { of useful heat, } \%\end{array}$ \\
\hline
\end{tabular}

The most significant changes and clarifications the following new methods:

(1) Added a new position on Coke: "7.2. indicator CSR" and "10. Substitution of coke with lump anthracite" and the position "23. The increase in the degree of melting force...".

(2) Clarification and differentiation effect recovery of manganese in cast iron and sulfur transfer to the slag, depending on the quantity of these components in the mixture (items $6,12,14$ ).

(3) Clarification in the direction of decreasing the coefficient of replacement of coke by natural gas at the rate greater than $100 \mathrm{~m}^{3} / \mathrm{t}$ (item 19) that is associated with the established in the course of the research the specific change of the temperature field of a heat charge materials in case of reduction degree of direct reduced below $20 \%$.

(4) Based on studies and mathematical modeling of processes in a blast furnace, burden materials distribution on a 10-point equal area annular zones of the cross section of the furnace top for the first time given the forecast assessment of the influence of character of distribution of material and gas on the basic parameters of melting in a quantitative form (item 27). In the first stage assessment is not included in the total adjustment of coke consumption, and is used in the comparative analysis. For inclusion will be developed differential scale distribution of ore loads on the radius of blast furnace.

(5) The possibility of estimation of influence of thermal losses on the coke consumption and productivity (item 28).

\section{Charging Options}

Since the content of iron in agglomerate depends on basicity, should operate the generalized index - iron concentration of conditionally self-fluxed charge. It is defined as the amount of iron in all components (including limestone, metal-additives, slag additives etc), in addition to coke, divided by the total consumption course of these components without $\mathrm{CO}_{2}$ carbonates. Thus, consumption of raw flux is the sum of the components of the charge less contained $\mathrm{CO}_{2}$. The specified index of the content of iron, you can compare the wealth blends with different basicity and exclude having a place ambiguity of the current rate of maintenance of iron in agglomerate. Iron content in semiсамоплавкой charge is surely connected with the release of slag on 1 t pig-iron. Therefore, the analysis can be operated on only one of these values.

Increased content of iron for every $1 \%$ at the same oxidation corresponds to the decrease in the number of slag value: $\Delta \amalg=100 \mathrm{Fe}_{\mathrm{\Psi}} /(\% \mathrm{Fe})^{2}, \mathrm{~kg} / \mathrm{thm}$.

where: $\mathrm{Fe}_{\mathrm{\varphi}}$ - the amount of iron in iron, $\mathrm{kg} / \mathrm{t}$ of pig iron;\% $\mathrm{Fe}$
- average content of $\mathrm{Fe}$ in self-fluxing charge, $\%$.

When $\mathrm{Fe}_{ч}=940 \mathrm{~kg} / \mathrm{t}$ and $\% \mathrm{Fe}=50 \%$ value $\Delta \amalg=37,6$ $\mathrm{kg} / \mathrm{t}$.

When $\mathrm{Fe}_{ч}=940 \mathrm{~kg} / \mathrm{t}$ and $\% \mathrm{Fe}=55 \%$ value $\Delta \amalg=31,0$ $\mathrm{kg} / \mathrm{t}$.

When $\mathrm{Fe}_{\mathrm{ч}}=940 \mathrm{~kg} / \mathrm{t}$ and $\% \mathrm{Fe}=60 \%$ value $\Delta \amalg=26,0$ $\mathrm{kg} / \mathrm{t}$.

With the average content of iron in agglomerate $50 \%$ of changing it to $1 \%$ leads to a change in the amount of slag 1.4 times greater than in the case of the average iron content of $60 \%$. For this reason, saving coke and increase productivity on the every additional $1 \%$ of iron in agglomerate obtained in conditions of Ukraine, 1.4 times higher than in Russia. Largely for this reason, the efficiency of increase iron content through the input to the charge of pellets in some cases lower than in the case of increasing the content of iron in agglomerate there. A decrease of the slag for every $10 \mathrm{~kg} / \mathrm{t}$ of pig iron contributes to the economy of coke $0,35 \%$ and a rise of productivity of $0.6 \%$ regardless of its total amount and content of iron in the charge.

Consumption of metal-additives affects the consumption of coke through the content of iron in agglomerate (number of slag) (item 1) and heat consumption and carbon on the direct reduction, changing under the influence of change of a degree of metallization, which is determined as the ratio of the number of metallic iron in the charge to the entire gland charge. Because the accounting for the maintenance of iron in agglomerate is provided in a separate item (item 1), the flow of net of metal-additives (item 2) takes into account only the change in metallization of charge. If necessary, isolated assessment of the impact of metal-additives when changing the number of slag is not accounted for separately, it should be taken into account (3-5 kg/t of pig iron slag for every $10 \mathrm{~kg} / \mathrm{t}$ of pig iron metal-additives) in General value of efficiency. Then saving coke from higher consumption of pure metal-additives $(100 \% \mathrm{Fe})$ for every $10 \mathrm{~kg} / \mathrm{t}$ of pig iron at $0.6 \%$, and the increase of the production capacity of $0.8 \%$. For contaminated metal-additives efficiency is proportional to $\mathrm{Fe}(\mathrm{kg} / \mathrm{kg})$.

The degree of fluxing the charge affects the consumption of coke and performance through the contents of iron and consumption of raw flux. The first factor is taken into account when counting those changes in the content of iron in the conditionally self-fluxing charge, the second should teach remain separately (item 3). Outlined the way of accounting for the characteristics of the charge eliminating the need to enter a dimension such as the share of sinter and pellets, as the latter affects the consumption of coke output slag (iron content), flux consumption (item 3) and coal content in the charge (item 4). 
Material characteristics coke (items 5, 6) and the composition of iron (items 10-13) affect the consumption of coke as directly through the heat balance and balance of carbon and through changes in the amount of slag and raw flux. Since the total change in the quantity of slag (Fe content) and crude flux is accounted for separately (items 1, 3), the value of the influence factors on the consumption of coke and performance under items 5, 6, 10-13 include only the effect of direct influence of factors on the heat balance and the balance of carbon.

If you want to evaluate the influence of each of the factors considered in isolation, when the total change in the amount of slag and raw flux is not accounted for separately, you should consider this change in the overall magnitude of impact of each factor on the consumption of coke and performance (table 2; the numerator in the absence in the charge of raw flux or constant consumption, denominator - if you change the quantity of $\mathrm{CaO}$ in charge change in the flow rate of raw flux).

Impact strength (item 7) and attrition (item 8) coke takes into account the have-growing mutual relationships between the indicators $\mathrm{M}_{25}$ and $\mathrm{M}_{10}$. If necessary, the isolated bathroom assessment of the impact of each of these indicators should be assessed increase for every $1 \%$ of the $\mathrm{M}_{25}$ savings of coke and increase the productivity of blast furnace $1.5 \%$, and the indicator $\mathrm{M}_{10}$ - values given in the table 1 .

Table 2. Isolated assessment of the impact factors on the specific consumption of coke and productivity of the blast furnace.

\begin{tabular}{|c|c|c|}
\hline \multirow{2}{*}{ Factors and units } & \multicolumn{2}{|l|}{ + increase, - decrease } \\
\hline & coke consumption, $\%$ & Productivity, $\%$ \\
\hline Reduction of ash content in the coke on $1 \%$ & $-1,4 /-1,8$ & $+1,4 /+1,8$ \\
\hline \multicolumn{3}{|l|}{ Reduction of the sulphur content in the coke } \\
\hline for every $0.1 \%$ of $[S]=0,05 \%$ & $-0,18 /-0,57$ & $+0,18 /+0,57$ \\
\hline$[S]=0,04 \%$ & $-0,22 /-0,70$ & $+0,22 /+0,70$ \\
\hline$[S]=0,03 \%$ & $-0,27 /-0,92$ & $+0,27 /+0,92$ \\
\hline$[S]=0,02 \%$ & $-0,38 /-1,36$ & $+0,38 /+1,36$ \\
\hline$[S]=0,01 \%$ & $-0,71 /-2,66$ & $+0,71 /+2,66$ \\
\hline Reduction in the content of silicon in the iron $0.1 \%$ & $-1,2 /-1,0$ & $+1,2 /+1,0$ \\
\hline Reduction of content of manganese in the iron & $\mathrm{\kappa g} /$ thm & $\%$ \\
\hline at $30 \% \mathrm{Mn}$ in the output $\mathrm{Mn}$-ore & $-1,17 /-1,66$ & $+0,22 /+0,33$ \\
\hline at $20 \% \mathrm{Mn}$ in the output $\mathrm{Mn}$-ore & $-1,76 /-2,89$ & $+0,35 /+0,42$ \\
\hline at $15 \% \mathrm{Mn}$ in the output $\mathrm{Mn}$-ore & $-2,27 /-3,78$ & $+0,44 /+0,61$ \\
\hline \multicolumn{3}{|l|}{ in case of the arrival of sulphur with the charge $10 \mathrm{~kg} / \mathrm{t}$} \\
\hline From 0.04 to $0.05 \%$ & $-3,3 /-13,0$ & $+0,6 /+2,4$ \\
\hline From 0.03 to $0.04 \%$ & $-5,5 /-21,7$ & $+1,1 /+4,3$ \\
\hline From 0.02 to $0.03 \%$ & $-11 /-43,3$ & $+2,0 /+7,19$ \\
\hline From 0.01 to $0.02 \%$ & $-33 /-130,0$ & $+6,5 /+25,6$ \\
\hline \multicolumn{3}{|l|}{ In case of the arrival of sulphur with the charge $4 \mathrm{~kg} / \mathrm{t}$} \\
\hline From 0.04 to $0.05 \%$ & $-1,3 /-5,1$ & $+0,25 /+0,99$ \\
\hline From 0.03 to $0.04 \%$ & $-2,2 /-8,7$ & $+0,4 /+1,58$ \\
\hline From 0.02 to $0.03 \%$ & $-4,4 /-17,4$ & $+0,8 /+3,15$ \\
\hline From 0.01 to $0.02 \%$ & $-13,3 /-52,4$ & $+2,5 /+9,85$ \\
\hline
\end{tabular}

\section{Blast Parameters}

The impact of the blow parameters on the specific consumption of coke and productivity of the furnace is characteristic of high non-linearity and dependence on many conditions. For this reason, the conversion factors given ranges of parameter values, and in dependence depending on the values of other parameters.

To the greatest extent it refers to the blast temperature, consumption of natural gas and oxygen.

The effect of the concentration of oxygen in the blast on the consumption of coke is ambiguous and depends on the initial conditions. When working on a cold or low-heated atmospheric blast oxygen additive promotes economy of coke. In the conditions of high-heated blast with a high concentration of oxygen and low hydrocarbons additional enrichment of blast oxygen without the addition of hydrocarbons leads to excessive consumption of coke. The second of these modes is typical for most modern furnaces that use oxygen when heated blast up to $1000-1300^{\circ} \mathrm{C}$. Some over-expenditure of coke (item 16) takes place on these furnaces, despite the reduction of specific heat losses in enrichment of blast oxygen (without additives of natural gas) with fixed (and in some cases less) direct reduction.

The coefficients of replacement (KR) coke gaseous and liquid blast-additives depend on all the parameters that determine the character of the temperature field in the furnace (item 14-19). Generally the more, the higher the original importance of the acquisition of theoretical combustion temperature. For the value, this temperature $2,000^{\circ} \mathrm{C}$. KR coke by natural gas is $0,9-1,0 \mathrm{~kg} / \mathrm{m}^{3}$ at low consumption, falling to $0.7-0.3 \mathrm{~kg} / \mathrm{m}^{3}$ at a consumption 150 $200 \mathrm{~m}^{3} /$ t. Similarly KR of coke by coke oven gas is $0.40-0.45$ $\mathrm{kg} / \mathrm{m}^{3}$. KR of fuel oil is little dependent on the total flow rate and is $1.4 \mathrm{~kg} / \mathrm{kg}$. KR of crushed coal is mainly determined by its composition and equal for anthracite $1.0 \mathrm{~kg} / \mathrm{kg}$, and for gas coals and lean coals $0,8-0,9 \mathrm{~kg} / \mathrm{kg}$. 
The values of KR of coke can be obtained in the case of complete transmutation of hydrocarbons, and solid carbon at the tuyeres. When existing ways of their input and distribution on tuyeres part of hydrocarbons subjected to pyrolysis with generation of soot and coal particles are burned incompletely. Given this, the practical value of KR coke adopted by $15-20 \%$ below the limit for natural gas, fuel oil and coal (items 18, 19, 20). For coke oven gas specified effect is negligible (item 17). Increased intensity of melting at forced during the process leads to the increase of the share of coke consumption. The value of the over consumption of coke from the higher-intensity of melting the more than lower specific consumption of coke and less of his strength, more small fractions in the furnace and a higher concentration of oxygen in the blast, as well as smaller stay charge materials in the furnace.

In the case of increasing the intensity due to factors that reduce the consumption of coke, for example, fines trifles of charge, sharing an increase in consumption of sour-kind and natural gas and other expenditure coke explicitly not observed and decreases the total value of savings. In this case, the influence of the intensity of the melting not require separate accounting as a component of the total value of changes in consumption of coke from the effects of the main factor. Separate accounting of the impact of melting intensity required in case of changes of intensity of gas-dynamic regime, which are expressed in the change of the differential pressure of gases in the furnace (item 25). This is due to changes in the volume of gases per unit of time with irregular gas permeability post of the charge, and also due to changes o permeability post of the charge for the same amount of gases per unit of time. The increase in differential pressure and a corresponding increase in the intensity of blast-melting leads to increased productivity of the furnace. The increase in differential pressure and a corresponding increase in the intensity of blast-melting leads to increased productivity of the furnace. The excess of some boundary differential pressure leads to an increase in consumption of coke and a corresponding slowdown in the growth of productivity of the furnace. The boundary values of differential pressure $\left(\Delta \mathrm{P}_{\mathrm{b}}\right)$ for blast furnaces of different volumes are approximately:

$$
\begin{gathered}
1000-1242 \mathrm{~m}^{3}-130 \mathrm{kPa} \\
1300-1800 \mathrm{~m}^{3}-140 \mathrm{kPa} \\
2000-2300 \mathrm{~m}^{3}-150 \mathrm{kPa} \text {; } \\
2700-3200 \mathrm{~m}^{3}-160 \mathrm{kPa} \\
5000 \mathrm{~m}^{3}-180 \mathrm{kPa}
\end{gathered}
$$

For the specific conditions they should be clarified by the expression:

$$
\Delta \mathrm{P}_{\mathrm{b}}=\Delta \mathrm{P}_{\mathrm{b}}{ }^{\mathrm{o}} \cdot 450 / \mathrm{k} \text {, where } \mathrm{k} \text { - coke consumption, } \mathrm{kg} / \mathrm{t} \text {. }
$$

\section{Fluctuations of the Charge Composition and Parameters of Technology}

Shown in the table 3 data are intended for isolated evaluation of each the Treaty of factors, when the total change in the quantity of slag, silicon content in the iron and differential pressure of gases in the post of the charge is not accounted for separately. When evaluating the influence of the complex of parameters (tab. 3), where the impact of the changes in the number of slag (maintenance of iron in agglomerate), silicon content in the iron and differential pressure in the furnace is recorded gross (regardless of the determining factors), separate accounting for the effects of variability charge composition and parameters of the heat is not required.

Table 3. The impact of fluctuations in the parameters on the consumption of coke and productivity of the furnace.

\begin{tabular}{lll}
\hline Reduction of RMS deviation factors & Savings coke, $\%$ & Performance Increase, $\%$ \\
\hline Error dosing of charge $0.1 \%$ & 0,28 & 0,42 \\
Coke humidity $0.1 \%$ & 0,28 & 0,42 \\
Ash coke $0.1 \%$ & 0,36 & 0,54 \\
Maintenance of iron in agglomerate by $0.1 \%$ & 0,20 & 0,29 \\
Basicity of charge 0.01 & $0,13-0,19$ & $0,22-0,33 *$ \\
The temperature of the blast $10^{\circ}$ & 0,08 & 0,13 \\
Humidity blast $0.1 \%$ & 0,45 & 0,67 \\
Natural gas consumption for $1 \mathrm{~m}^{3} / \mathrm{t}$ & 0,42 & 0,63 \\
The concentration of oxygen in the blast $0.1 \%$ & - & 0,22 \\
\hline
\end{tabular}

* Smaller values when exiting slag $300-350 \mathrm{~kg} / \mathrm{t}$ of pig iron, large - at 450-500 kg/t of cast iron.

\section{Organizational Factors and General Comments}

The institutional factors technologies relate stop and quiet running up-term furnaces, rhythm charging and tapping, as well as associated with these factors stability of the process. The influence of these factors on the specific coke consumption and productivity of the furnace depends on the nature of transients caused by them, and therefore not always explicitly. Until this influence is assessed empirically, based mainly on the statistical production data (items 22-24). Sufficiently studied and largely amenable to quantitative analysis within a single logical scheme of blast-furnace smelting. The influence of some of them, studied not enough is considered in isolation, on the basis of generalization of experimental data. These include mechanical and physical- 
chemical properties of raw materials and coke, natural gas distribution in the furnace, the characteristics and dynamics of changes of elements of the profile of the furnace (and therefore heat loss), processes in the forge migration alkalis and carbon.

These factors with direct impact on the specific consumption of coke and productivity of the furnace, are in close relation with other parameters of melting and may modify the nature of the influence of these parameters on the indicators of the processes. For reliable their assessment requires further study and mathematical description of processes. At this stage uses only some empirical data (items $4,7,8,22-24)$.

\section{Conclusion}

Based on the study and mathematical modeling of the processes of blast furnace melting, as well as the generalization of the operating experience of the furnace furnaces, general principles for their functioning have been established and a normative assessment of the effect of process parameters on coke consumption and blast furnace capacity is given. This normative assessment is the methodological basis for performing an operative analysis of technology and the content base of the guiding technological document used at enterprises since 1987.

The new document was substantially supplemented and refined based on the results of the analytical and experimental studies carried out in the past years, as well as the generalization of the experience of the operation of blast furnaces. This version for the first time has an effect on the coke consumption of the nature of charge material distribution during loading.

\section{References}

[1] Tovarovskiy I. G. The study of the influence of technological factors on the specific consumption of coke and the productivity of a blast furnace in a wide range of conditions with the establishment of scientifically based standards // Abstracts at the All-Union Scientific and Technical Conference "Improving the Technical Level and Improving the Technology of Blast Furnace Production", Lipetsk, May 1982, Chermetin formation ", 1982, p. 14-17. Товаровский И. Г. Изучение влияния технологических факторов на удельный расход кокса и производительность доменной печи в широком диапазоне условий с установлением научно обоснованных нормативов // Тезисы докладов на Всесоюзном научно-техническом совещании "Повышение технического уровня и совершенствование технологии доменного производства", Липецк, май 1982, “Черметинформация", 1982, с. 14-17.

[2] Tovarovsky IG, Khomich V. N. Principles of the evaluation of the influence of technological factors on the parameters of blast furnace melting // Stal.-1979.-№ 12. Товаровсккий И. Г., Хомич В. Н. Принципы оценки влияния технологиче-ских факторов на показатели доменной плавки // Сталь.-1979.№ 12.-C. 895-898.

[3] Tovarovsky I. G. The influence of technological factors on the specific consumption of coke and the reproducibility of a blast furnace // Sb. (Branch) "Economy of coke in blast furnaces", M., Metallurgy, 1986, p. 75-83. Товаровский И. Г. Влияние технологических факторов на удельный расход кокса и проиводительность доменной печи // Сб. трудов (отраслевой) “Экономия кокса в доменных печах"., М., “Металлургия”,1986, с. 75-83.

[4] Ministry of Ferrous Metallurgy of the USSR. Technical management. Insitute of ferrous metallurgy. // BLAST FURNACES. NORMATIVE EXPENSE OF COKE. Guidance document. Moscow - Dnepropetrovsk. 1987, pp. 1 - 14. Министерство черной металлургии СССР. Техническое управление. Институт черной металлургии. //ДОМЕННЫЕ ПЕЧИ. НОРМАТИВЫ РАСХОДА КОКСА. Руководящий документ. Москва - Днепропетровск. 1987 г. C. $1-14$.

[5] M. A. Pavlov. Metallurgy of cast iron. Part 2. The blastfurnace process. - Sixth edtion. - M.: Metallurgizdat, 1949. 628 р. Павлов М. А. Металлургия чугуна. Ч. 2. Доменный процесс. - Издание шестое. - М.: Металлургиздат, 1949. $628 \mathrm{c}$.

[6] Diepschlag E. Der Hochofen. - Leipzig.: Ferlag von Otto Spamer. - 1932. В пе реводе с немецкого под редакцией A. Н. Похвиснева: Дипшляг Е. Доменный процесс. -ХарьковДнепропетровск: Гос. н-техн. изд Украины, 1935. - 352 с.

[7] Ramm A. N. Modern blast furnace process. Moscow."Metallurgy".- 1980.-304 p. Рамм А. Н. Современный доменный процесс. Москва.- «Металл. ургия».- 1980.- 304 с.

[8] Tovarovskiy I. G. Cognition processes and development of a technology for blast-furnace production // Dnepropetrovsk: "Gurfund". - 2015. - 912 р. Товаровский И. Г. Познание процессов и развитие технологии доменной плавки // Днепропетровск: изд-во «Журфонд». - 2015.- 912 с.

[9] A. Babich, D. Senk, H. W. Gudenau, K. Th. Mavrommatis IRONMAKING.

[10] Cognition the processes and development the technology of blast smelting. Collective scientific work of the Second international Symposium, edited by I. G. Tovarovskiy. Dnipropetrovsk.- publishing house "Gurfund".-2016.-382 p. Познание процессов и развитие технологии доменной плавки. - Коллективный научный труд Второго международного симпозиума под редакцией И. Г. Товаровского. - Днепропетровск.- издательство «Журфонд».-2016.-382 с.

[11] Tovarovskiy I. G. The Philosophy of the Blast Smelting: Cognition and development of the technology. Science Journal of Energy Engeneering. Vol. 5. No. 1, 2017, pp. 31-39, doi: 10,11648/j.sjee20170501.13. 